International Journal of Finance and Accounting (IJFA)

INVENTORY CONTROLS AND FINANCIAL PERFORMANCE OF MARISSA COUNTY GOVERNMENT, KENYA 


\title{
INVENTORY CONTROLS AND FINANCIAL PERFORMANCE OF GARISSA COUNTY GOVERNMENT, KENYA
}

\author{
1* Mohamed Hussein Nur \\ 1*Post graduate student, Kenyatta University \\ *Corresponding Author's Email: somanepgh@gmail.com \\ ${ }^{2 *}$ Dr Jeremiah Koori \\ Lecturer, Kenyatta University
}

\begin{abstract}
Purpose: The purpose of the study was to examine inventory controls and financial performance of Garissa county government, Kenya.

Methodology: The study adopted a descriptive research design. The target population of the study was all the 250 employees in the Garissa county treasury department. The sample size was 70 employees in the Garissa county treasury department who was selected using stratified random sampling. Primary data was collected through the administration of the questionnaires.

Results: The study found that that inventory recording have a positive and a significant effect on financial sustainability. The study also found that stock taking has a positive and a significant effect on financial sustainability. Also the study found that E-procurement had a positive and a significant effect on financial sustainability. Lastly, the study found that inventory management training has a positive and a significant effect on financial sustainability.

Unique contribution to theory, practice and policy: The study recommends that the county governments adopting e-procurement ought to scale down on traditional procurement activities if the benefits of e-procurement are to be realized. Additionally, it is recommended that county governments should focus more on streamlining e-tendering, e-requisitioning and e-sourcing because a strong and significant relationship exists between those e-procurement processes and procurement performance in supermarkets.
\end{abstract}

Key Words: inventory recording, stock auditing, E-procurement, inventory management training, financial performance 


\subsection{INTRODUCTION}

\subsection{Background of the Study}

The creation of county government in countries of the world is borne out of decentralization in order to ensure development at the grass root levels. County governments are better positioned to identify pressing needs of communities and ways of meeting such needs. Also, mobilization and participation of citizens in government is enhanced by the county government (Usang \& Salim, 2016). In essence, local governments are positioned to bring the government closer to the grass roots for the overall development of the country. This way, citizens are mobilized for participation in leadership and this creates a platform for mentoring potential political administrators. However, county governments across the globe are faced with issues that limit their capability to meaningfully improve the wellbeing of communities. According to Caruson, MacManus and McPhee (2012), county government experience financial pressures, increasing services challenges due to rising demand and insider threats.

Performance management in the public sector is the managerial activity necessary to promote well-performing policy management and service delivery (Dwivedi \& Jain, 2005). Organizational performance management in a government context concerns monitoring the success of public policy, programmes or projects in achieving their objectives and in securing the expected benefits. According to Prowle (2010), public sector organizations deal with large amounts of public funds and operation a largely political environment, thereby necessitating a need for a high degree of confidence in the way in which their financial affairs are being conducted. In view of improving the performance most public sectors globally have established inventory control strategies in order to enhance their financial reporting systems, check on their efficiency and effectiveness of operations as well as enhance adherence to the prescribed rules and regulations (Mary et al., 2015

In inventory control, audit of inventory is required. Audit of inventory is important in many organizations as misstatement affect reported profit: misstatement of inventory balances has a direct effect on reported profit as inadequate or inappropriate inventory held can fail to meet the demands of sales and production requirements; high inventory levels resulting in poor cash flow and financial loss; inaccurate or incomplete record of inventory movements resulting in lack of awareness of the actual inventory position and difficulties in meeting customer needs; lack of security over inventory resulting in loss, theft or misappropriation and obsolete inventory held or incorrectly supplied to customers, results in financial loss and damage to reputation (Bedard \& Wright, 2000).

In addition E procurement is also very important in inventory control. This is because it reduces inventory levels, improves auditing and financial control, eliminates paperwork, enhance staff efficiency and shorten delivery time. An automated inventory and procurement solution also saves time by streamlining purchasing and inventory control. Tasks that once took hours or even days can be performed with a few clicks of a mouse. Staff no longer wastes time matching receipts with deliveries, figuring out overly complex invoices and keying in redundant information. An automated inventory and procurement solution increases accuracy 


\subsection{Statement of the problem}

Good performance of Kenya's county government is critical due to the important role that these governments play in the country (Ochara, 2010). In Garissa County, the revenue collected in the year 2014/2015 was Ksh 96 million while the targeted revenue was Ksh 500 million per year and therefore the county fell short of its revenue collection target. In the year 2013/2014 the revenue collected was Ksh 39.5 million while the targeted revenue was Ksh 500 million per year. This therefore has led to the deficit in the county government budget.

In addition the Garissa county government in its 2013-2014 financial budget, allocated substantial amounts of resources for the implementation of ICT-based systems in operations of all the crucial departments among them procurement department. Inventory department that accounts for the largest portion of its assets has been given the highest priority in this case (Christopher \& Kwasira (2012). However, in spite of these heavy allocations, the revenue collection has never surpassed the target. It is in this spirit of improving and enhancing the performance of the county government that this study was carried out to examine the effect of inventory control and financial performance of Garissa county government, Kenya.

\subsection{Objectives of the Study}

The main objective of the study was to examine inventory controls and financial performance of Garissa county government, Kenya.

\subsubsection{Specific Objectives}

The specific Objectives of the study were;

i. To establish the effect of inventory recording on financial performance of Garissa county government, Kenya

ii. To determine the effect of stock auditing on financial performance of Garissa county government, Kenya

iii. To evaluate the effect of E - procurement on financial performance of Garissa county government, Kenya

iv. To examine the effect of inventory management training on financial performance of Garissa county government, Kenya.

\subsection{LITERATURE REVIEW}

\subsection{Empirical Review}

In a study conducted in Brazil by Carvalho (2000), it was noted that limited provision of nonAmaka (2012) conducted a study on the relationship between internal measures to proper accounting records. A survey research design was adopted for this research study and a sample size was selected using Yaro Yamane sampling technique as data used were obtained from both primary and secondary sources. Four research questions were formulated out of which three hypothesis were formulated using regression co-efficient analysis method at 5\% level of significance and the $\mathrm{Z}$ table was also used for comparison between calculated value of significance $B$ and table value. The finding from the analysis indicates that internal control 
measure management performance and is necessary for the growth and effectiveness of the organization.

Wambua, Okibo, Nyang'au and Ondieki (2015) investigated the effects of the management of warehousing inventory systems on Seventh day Adventist institution's financial performance in Kenya. The main objective is to evaluate the effects of inventory warehousing systems on Seventh Day Adventist Institution's financial performance. The specific objective that guided this research was to assess the effect of Inventory warehousing systems on the financial performance of Adventist Book Centers. The researcher used descriptive research design in undertaking this study. The target population was 216 employees at HHES while sample size was $30 \%$ of the target population totaling to 64 employees. The empirical results revealed a positive significant relationship between financial performance and Inventory warehousing system

Ziaee (2014) conducted a study on the effect of audit quality on the performance of listed companies in Tehran Stock Exchange. According to this study a firm engages in opinion shopping by influencing or even manipulating its auditor's decision in certain ways to obtain an opinion that is more favorable that that warranted by the quality of its accounting information. If such behavior exists, then it would lead to a higher degree of information asymmetry between managers and investors and weaken auditing protective effect on investors. Many researchers have been done to improve the understanding of audit quality to a better understanding. This concept can be achieved and the relationship between audit quality and other parameters to be determined. The study concluded that there is a positive significant relationship between audit quality and auditor size.

Gaturu and Ngahu (2014) conducted a study on the effect of computerized audit system on financial management at water resources management authority in Nairobi County, Kenya. The study was conducted in WRMA headquarters based in Nairobi, Kenya. Descriptive research design was employed. The study established that computer-assisted audit techniques and internal controls influenced financial management in WRMA. The study recommended that WRMA should have sound CAATs put in place to identify errors and mitigate financial misappropriation. The internal controls adopted ought to be effective and fully adhere to.

Sugut (2014) conducted a study on the effect of computerized accounting systems on the quality of financial reports of non-governmental organizations in Nairobi County, Kenya. The study found out that taking all other independent variables at zero, a unit increase in transparency lead to 0.478 increases in quality of financial reports.

\subsection{Theoretical Review}

\subsubsection{Agency Theory}

Agency theory was initiated by Jensen and Meckling (1976). It describes firms as necessary structures to maintain contracts, and through firms, it is possible to exercise control which minimizes opportunistic behavior of agents. In order to harmonize the interests of the agent and the principal, a comprehensive contract is written to address the interest of both the agent and the principal. The relationship is further strengthened by the principal employing an expert to monitor the agent (Barlie \& Means, 1932). This position is also supported by Coarse (1937) who 
maintains that the contract provides for conflict resolution between the agent and principal, the principal determines the work and agent undertakes the work.

The theory recognizes the incomplete information about the relationship, interests or work performance of the agent described as adverse selection and moral hazard. Moral hazard and adverse selection affects the output of the agent in two ways; not doing exactly what the agent is appointed to do, and not possessing the requisite knowledge about what should be done. This affects the overall performance of the relationship as well as the benefits of the principal in the form of cash residual.

\subsubsection{Contingency Theory}

Contingency theory posits the view that there is no universal control system that is best but that the circumstances or context faced by the organization determine which control systems is appropriate (Waterhouse \& Tiessen, 1978: Gordon \& Miller, 1976: Watson, 1975) .Organizations and their functions depend on various external and internal factors. The functions of audits are themselves, types of organizations that are affected by various factors in the environment. The presence of such factors is why auditing can be managed by applying the contingency theory, with a recognition that processes and outcomes of audits are dependent on variable and contingent factors (Watson, 1975).

\subsection{METHODOLOGY}

The study adopted a descriptive research design. The target population of the study was all the 250 employees in the Garissa county treasury department. The sample size was 70 employees in the Garissa county treasury department who was selected using stratified random sampling. Primary data was collected through the administration of the questionnaires.

\subsection{RESULTS AND DISCUSSIONS}

\subsection{Bio data Analysis}

This section consisted of information that describes basic characteristics such as gender of the respondent, number of years worked and the years of operation of the hospital.

\subsubsection{Gender of the Respondents}

The respondents were asked to indicate their gender. The results were presented in figure 1 below.

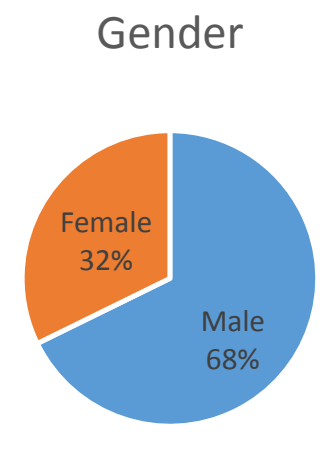




\section{Figure 1: Gender of the Respondents}

The results indicated that majority of the respondents who were $68 \%$ were males while only $32 \%$ were female. This implies that most employees in the Garissa county treasury department were men.

\subsubsection{Age of the Respondents}

The respondents were asked to indicate their age. The results were indicated in figure 2 below.

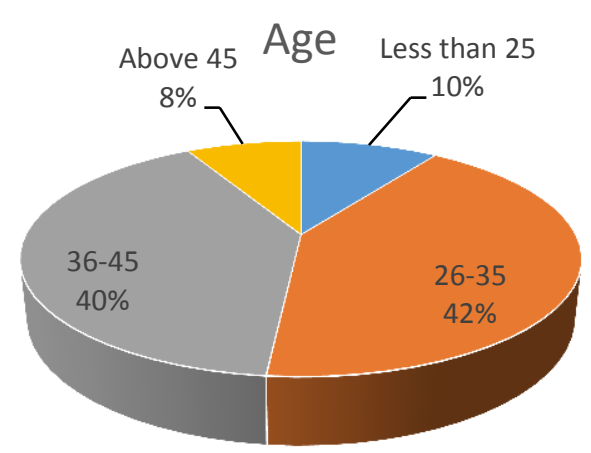

\section{Figure 2: Age of the Respondents}

Majority of the respondents who were $42 \%$ were $26-35$ years, $40 \%$ of the respondents were 36 - 45 years, $10 \%$ of the respondents were less than 25 years while only $8 \%$ were above 45 years. This implied that most of the employees in the Garissa county treasury department were middle aged people.

\subsubsection{Level of Education}

The respondents were asked to indicate their level of education. The results were indicated in figure 4.3 below.

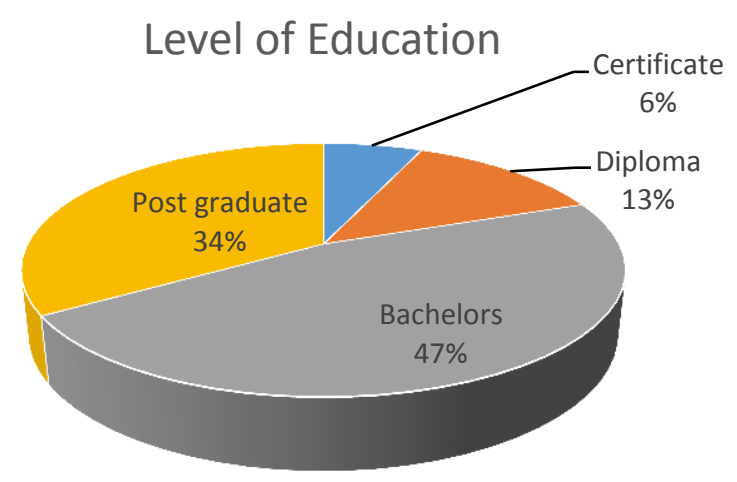

\section{Figure 3: Level of Education}




\section{www.iprjb.org}

Majority of the respondents who were $47 \%$ had bachelors degree, $34 \%$ of the respondents had post graduate degree, $13 \%$ of the respondents had diploma while only $6 \%$ had certificate. This implied that most of the employees in the Garissa county treasury department were educated people.

\subsubsection{Years Worked}

The respondents were also asked to indicate the years worked in the county treasury. The results were shown in figure 4 below.

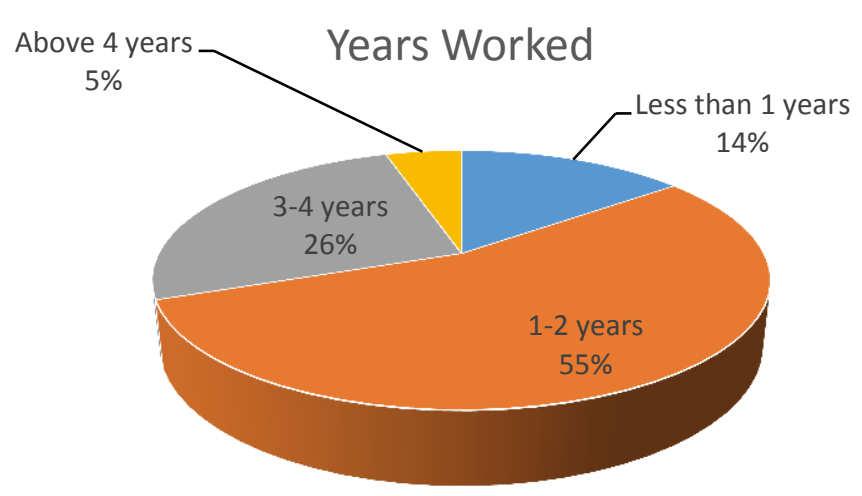

\section{Figure 4: Years Worked}

Majority of the respondents who were 55\% indicated that they had worked in the county treasury department for $1-2$ years, $26 \%$ of the respondents indicated that they had worked for $3-4$ years, $14 \%$ indicated that they had worked for less than 1 year while only $5 \%$ had worked for above 4 years.

\subsection{Inventory Recording and Financial Performance}

Table 1: Inventory Recording and Financial Performance

\begin{tabular}{|c|c|c|c|c|c|c|c|}
\hline Statement & $\begin{array}{l}\text { Strongly } \\
\text { Disagree }\end{array}$ & Disagree & Neutral & Agree & $\begin{array}{l}\text { Strongly } \\
\text { Agree }\end{array}$ & Mean & Std. Dev \\
\hline $\begin{array}{l}\text { Receiving documents } \\
\text { are matched to } \\
\text { purchase orders and } \\
\text { invoices }\end{array}$ & $6.50 \%$ & $17.70 \%$ & $14.50 \%$ & $45.20 \%$ & $16.10 \%$ & 3.47 & 1.16 \\
\hline $\begin{array}{l}\text { Inventory records are } \\
\text { maintained based on } \\
\text { periodic physical } \\
\text { counts or a perpetual } \\
\text { system }\end{array}$ & $4.80 \%$ & $14.50 \%$ & $6.50 \%$ & $50.00 \%$ & $24.20 \%$ & 3.74 & 1.13 \\
\hline $\begin{array}{l}\text { Garissa county } \\
\text { government keep } \\
\text { accurate inventory } \\
\text { records }\end{array}$ & $4.80 \%$ & $16.10 \%$ & $12.90 \%$ & $46.80 \%$ & $19.40 \%$ & 3.71 & 1.21 \\
\hline $\begin{array}{l}\text { There are inventory } \\
\text { warehousing systems }\end{array}$ & $8.10 \%$ & $9.70 \%$ & $4.80 \%$ & $51.60 \%$ & $25.80 \%$ & 3.77 & 1.18 \\
\hline
\end{tabular}


in the Garissa county

government

Inventory recording affects performance of

the county government

Average
$3.20 \%$

$16.10 \%$

$1.60 \%$

$41.90 \%$

$37.10 \%$

3.94

1.16

3.73

1.17

\section{Source: Survey Data (2017)}

The results revealed that majority of the respondents who were $61.3 \%(45.2 \%+16.1 \%)$ agreed with the statement that receiving documents are matched to purchase orders and invoices. The results further revealed that majority of the respondents who were $74.2 \%$ agreed with the statement that inventory records are maintained based on periodic physical counts or a perpetual system. The results further revealed that majority of the respondents who were $66.2 \%$ agreed with the statement that Garissa county government keep accurate inventory records. The results further revealed that majority of the respondents who were $77.4 \%$ agreed with the statement that there are inventory warehousing systems in the Garissa county government. The results further showed that majority of the respondents who were $79.0 \%$ agreed with the statement that inventory recording affects performance of the county government.

The respondents were further asked to indicate other effect inventory recording have on financial performance of the county. Majority of the respondents indicated that inventory recording affects return on assets of the company

\subsection{Stock Auditing and Financial Performance}

Table 2: Stock Auditing and Financial Performance

\begin{tabular}{|c|c|c|c|c|c|c|c|}
\hline Statement & $\begin{array}{l}\text { Strongly } \\
\text { Disagree }\end{array}$ & Disagree & Neutral & Agree & $\begin{array}{l}\text { Strongly } \\
\text { Agree }\end{array}$ & Mean & Std.Dev \\
\hline $\begin{array}{l}\text { The number of } \\
\text { locations that need to be } \\
\text { audited in the county } \\
\text { affects the financial } \\
\text { performance }\end{array}$ & $8.10 \%$ & $8.10 \%$ & $33.90 \%$ & $46.80 \%$ & $3.20 \%$ & 3.29 & 0.96 \\
\hline $\begin{array}{l}\text { There is transparency in } \\
\text { stock audit in the } \\
\text { county }\end{array}$ & $6.50 \%$ & $3.20 \%$ & $11.30 \%$ & $56.50 \%$ & $22.60 \%$ & 3.85 & 1.02 \\
\hline $\begin{array}{l}\text { The total count of stock } \\
\text { that is available in the } \\
\text { county affects the } \\
\text { financial performance }\end{array}$ & $3.20 \%$ & $3.20 \%$ & $9.70 \%$ & $61.30 \%$ & $22.60 \%$ & 3.97 & 0.87 \\
\hline $\begin{array}{l}\text { There is professional } \\
\text { excellence among the } \\
\text { audit team in stock } \\
\text { auditing }\end{array}$ & $4.80 \%$ & $16.10 \%$ & $14.50 \%$ & $50.00 \%$ & $14.50 \%$ & 3.53 & 1.08 \\
\hline $\begin{array}{l}\text { Stock audit affects } \\
\text { financial performance } \\
\text { of the county }\end{array}$ & $3.20 \%$ & $12.90 \%$ & $4.80 \%$ & $51.60 \%$ & $27.40 \%$ & 3.87 & 1.06 \\
\hline Average & & & & & & 3.70 & 1.00 \\
\hline
\end{tabular}


The results revealed that majority of the respondents who were $50.0 \%(46.8 \%+3.2 \%)$ agreed with the statement that the number of locations that need to be audited in the county affects the financial performance. The results also revealed that majority of the respondents who were $79.1 \%$ agreed with the statement that there is transparency in stock audit in the county. The results further showed that majority of the respondents who were $83.9 \%$ agreed with the statement that the total count of stock that is available in the county affects the financial performance. The results also showed that majority of the respondents who were $64.5 \%$ agreed with the statement that there is professional excellence among the audit team in stock auditing. The results also showed that majority of the respondents who were $79.0 \%$ agreed with the statement that stock audit affects financial performance of the county.

On a five point scale, the average mean of the responses was 3.70 which mean that majority of the respondents were agreeing with most of the statements; however the answers were varied as shown by a standard deviation of 1.00 .

The respondents were further asked to rate the process of stock audit in their county. Majority of the respondents indicated that it was fairly good.

\subsection{E - Procurement and Financial Performance}

Table 3: E - Procurement and Financial Performance

\begin{tabular}{|c|c|c|c|c|c|c|c|}
\hline Statement & $\begin{array}{l}\text { Strongly } \\
\text { Disagree }\end{array}$ & Disagree & Neutral & Agree & $\begin{array}{l}\text { Strongly } \\
\text { Agree }\end{array}$ & Mean & $\begin{array}{l}\text { Std. } \\
\text { Dev }\end{array}$ \\
\hline $\begin{array}{l}\text { E procurement affects } \\
\text { financial performance of } \\
\text { the county }\end{array}$ & $6.50 \%$ & $0.00 \%$ & $6.50 \%$ & $56.50 \%$ & $30.60 \%$ & 4.05 & 0.98 \\
\hline $\begin{array}{l}\text { Highly automated counties } \\
\text { perform better than a } \\
\text { county that still uses } \\
\text { manual systems. }\end{array}$ & $6.50 \%$ & $1.60 \%$ & $8.10 \%$ & $53.20 \%$ & $30.60 \%$ & 4.00 & 1.02 \\
\hline $\begin{array}{l}\text { There is extensive use of } \\
\text { ICT in the county } \\
\text { government }\end{array}$ & $6.50 \%$ & $3.20 \%$ & $8.10 \%$ & $54.80 \%$ & $27.40 \%$ & 3.94 & 1.04 \\
\hline $\begin{array}{l}\text { Removed manual tasks } \\
\text { leads to increased financial } \\
\text { performance in the county } \\
\text { government }\end{array}$ & $3.20 \%$ & $1.60 \%$ & $6.50 \%$ & $58.10 \%$ & $30.60 \%$ & 4.11 & 0.98 \\
\hline Average & & & & & & 4.03 & 1.01 \\
\hline
\end{tabular}

The results revealed that majority of the respondents who were $81.7 \%(56.5 \%+30.6 \%)$ agreed with the statement that $\mathrm{E}$ procurement affects financial performance of the county. The results also showed that majority of the respondents who were $83.8 \%$ agreed with the statement that highly automated counties perform better than a county that still uses manual systems. The results also showed that majority of the respondents who were $82.2 \%$ agreed with the statement that there is extensive use of ICT in the county government. The results further showed that majority of the respondents who were $88.7 \%$ agreed with the statement that removed manual tasks leads to increased financial performance in the county government. 
On a five point scale, the average mean of the responses was 4.03 which mean that majority of the respondents were agreeing with most of the statements; however the answers were varied as shown by a standard deviation of 1.01 .

The respondents were further asked to give advice to other county concerning use of E procurement. Majority of the respondents indicated that county governments adopting eprocurement ought to scale down on traditional procurement activities if the benefits of eprocurement are to be realized.

\subsection{Inventory Management Training and Financial Performance}

Table 4.4: Inventory Management Training and Financial Performance

\begin{tabular}{|c|c|c|c|c|c|c|c|}
\hline Statement & $\begin{array}{l}\text { Strongly } \\
\text { Disagree }\end{array}$ & Disagree & Neutral & Agree & $\begin{array}{l}\text { Strongly } \\
\text { Agree }\end{array}$ & Mean & $\begin{array}{l}\text { Std. } \\
\text { Dev }\end{array}$ \\
\hline $\begin{array}{l}\text { All employees in the } \\
\text { training department undergo } \\
\text { inventory training }\end{array}$ & $4.80 \%$ & $4.80 \%$ & $17.70 \%$ & $46.80 \%$ & $25.80 \%$ & 3.84 & 1.03 \\
\hline $\begin{array}{l}\text { There are seminars on } \\
\text { inventory controls }\end{array}$ & $9.70 \%$ & $1.60 \%$ & $11.30 \%$ & $50.00 \%$ & $27.40 \%$ & 3.84 & 1.15 \\
\hline $\begin{array}{l}\text { There is coaching and } \\
\text { mentorship program on } \\
\text { inventory control }\end{array}$ & $4.80 \%$ & $6.50 \%$ & $12.90 \%$ & $46.80 \%$ & $29.00 \%$ & 3.89 & 1.06 \\
\hline $\begin{array}{l}\text { There exists career } \\
\text { progression/path of } \\
\text { employees in the county }\end{array}$ & $11.30 \%$ & $6.50 \%$ & $12.90 \%$ & $53.20 \%$ & $16.10 \%$ & 3.56 & 1.18 \\
\hline $\begin{array}{l}\text { Senior managers and } \\
\text { supervisors nominate } \\
\text { employees for training }\end{array}$ & $8.10 \%$ & $8.10 \%$ & $16.10 \%$ & $27.40 \%$ & $40.30 \%$ & 3.84 & 1.27 \\
\hline Average & & & & & & 3.79 & 1.14 \\
\hline
\end{tabular}

The results revealed that majority of the respondents who were $72.6 \%(46.8 \%+25.8 \%)$ agreed with the statement that all employees in the training department undergo inventory training. The results further showed that majority of the respondents who were $77.4 \%$ agreed with the statement that there are seminars on inventory controls. The results further showed that majority of the respondents who were $75.8 \%$ agreed with the statement that there is coaching and mentorship program on inventory control. The results further showed that majority of the respondents who were $69.3 \%$ agreed with the statement that there exists career progression/path of employees in the county. The results further showed that majority of the respondents who were $67.7 \%$ agreed with the statement that senior managers and supervisors nominate employees for training.

On a five point scale, the average mean of the responses was 3.79 which mean that majority of the respondents were agreeing with most of the statements; however the answers were varied as shown by a standard deviation of 1.14 .

The respondents were further asked to indicate the challenges they encounter in inventory management training in the county. Majority of the respondents indicated lack of finances to support training programs. 


\subsection{Financial Performance}

The respondents were asked to rate the performance of Garissa County Government. The results were presented in figure 1 .

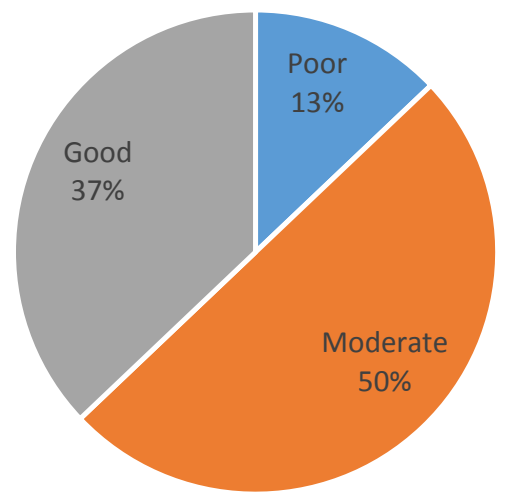

\section{Figure 1: Rate of Performance}

Majority of the respondents who were $50 \%$ indicated moderate, $37 \%$ indicated good while only $13 \%$ who indicated poor. This implies that performance of Garissa county government requires improvement.

\section{Table 5: Financial Performance}

\begin{tabular}{|c|c|c|c|c|c|c|c|}
\hline Statements & $\begin{array}{l}\text { Strongly } \\
\text { Disagree }\end{array}$ & Disagree & Neutral & Agree & $\begin{array}{l}\text { Strongly } \\
\text { Agree }\end{array}$ & Mean & $\begin{array}{l}\text { Std. } \\
\text { Dev }\end{array}$ \\
\hline $\begin{array}{l}\text { All employees in } \\
\text { the training } \\
\text { department undergo } \\
\text { inventory training }\end{array}$ & $6.50 \%$ & $6.50 \%$ & $8.10 \%$ & $37.10 \%$ & $41.90 \%$ & 4.02 & 1.17 \\
\hline $\begin{array}{l}\text { There are seminars } \\
\text { on inventory } \\
\text { controls }\end{array}$ & $6.50 \%$ & $4.80 \%$ & $9.70 \%$ & $27.40 \%$ & $51.60 \%$ & 4.13 & 1.18 \\
\hline $\begin{array}{l}\text { There is coaching } \\
\text { and mentorship } \\
\text { program on } \\
\text { inventory control }\end{array}$ & $9.70 \%$ & $12.90 \%$ & $0.00 \%$ & $21.00 \%$ & $56.50 \%$ & 4.02 & 1.41 \\
\hline $\begin{array}{l}\text { There exists career } \\
\text { progression/path of } \\
\text { employees in the } \\
\text { county }\end{array}$ & $4.80 \%$ & $6.50 \%$ & $16.10 \%$ & $54.80 \%$ & $17.70 \%$ & 3.74 & 0.99 \\
\hline $\begin{array}{l}\text { Senior managers } \\
\text { and supervisors } \\
\text { nominate } \\
\text { employees for } \\
\text { training }\end{array}$ & $3.20 \%$ & $14.50 \%$ & $30.60 \%$ & $33.90 \%$ & $17.70 \%$ & 3.48 & 1.05 \\
\hline
\end{tabular}


The results showed that majority of the respondents who were $79.0 \%$ agreed with the statement that all employees in the training department undergo inventory training. The results further showed that majority of the respondents who were $79.0 \%$ agreed with the statement that there are seminars on inventory controls in the county government. The results further showed that majority of the respondents who were $77.5 \%$ agreed with the statement that there is coaching and mentorship program on inventory control in the county government. The results further showed that majority of the respondents who were $72.5 \%$ agreed with the statement that there exists career progression/path of employees in the county in the county government. The results further showed that majority of the respondents who were $51.6 \%$ agreed with the statement that senior managers and supervisors nominate employees for training in Garissa county government.

\section{Surplus/Deficits}

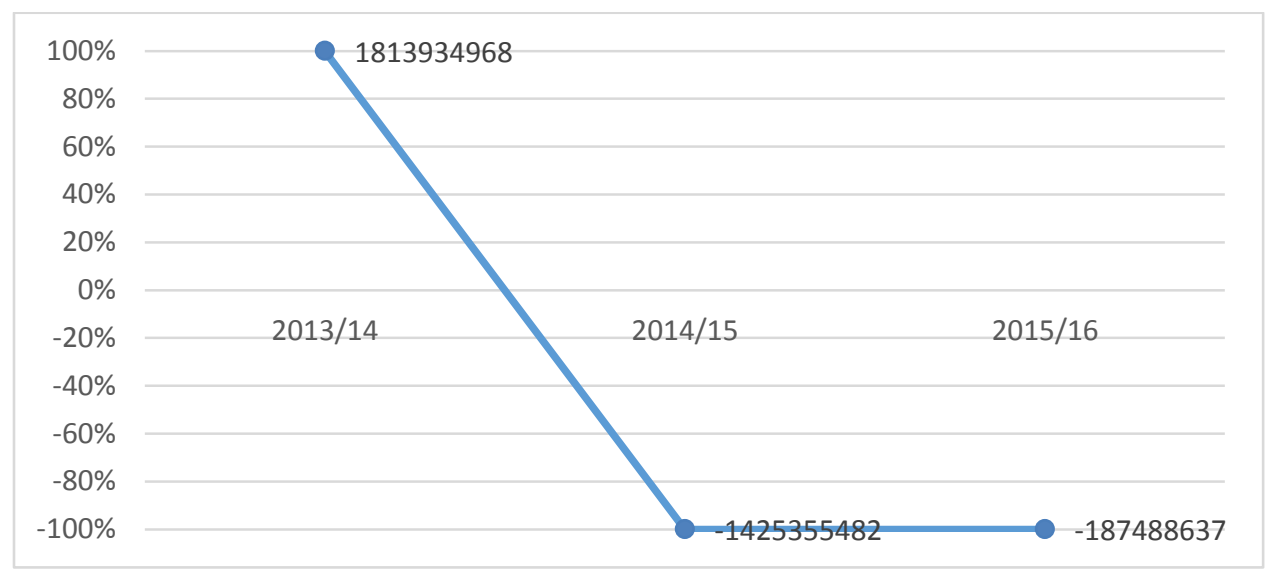

\section{Figure 6: Surplus/Deficit}

The results revealed that in the financial year 2013/2014 Garissa county government had a surplus of $1,813,934,968$. The results also showed that in the financial year 2014/2015 Garissa county government had a deficit of $1,425,355,482$. The results also showed that in the financial year 2015/2016 Garissa county government had a deficit of 187,488,637. This implies that the performance of Garissa county government have been declining over the years.

\subsection{Correlation Analysis}

Table 7: Correlational Analysis

\begin{tabular}{|c|c|c|c|c|c|c|}
\hline & & $\begin{array}{l}\text { Financial } \\
\text { Performance }\end{array}$ & $\begin{array}{l}\text { Inventory } \\
\text { recording }\end{array}$ & $\begin{array}{l}\text { Stock } \\
\text { Audit }\end{array}$ & E-procurement & $\begin{array}{l}\text { Inventory } \\
\text { Training }\end{array}$ \\
\hline Financial & Pearson & & & & & \\
\hline \multirow[t]{2}{*}{ Performance } & Correlation & 1.000 & & & & \\
\hline & Sig. (2-tailed) & & & & & \\
\hline Inventory & Pearson & & & & & \\
\hline \multirow[t]{2}{*}{ Recording } & Correlation & $.463 * *$ & 1.000 & & & \\
\hline & Sig. (2-tailed) & 0.000 & & & & \\
\hline Stock Audit & Pearson & $.427 * *$ & $.392 * *$ & 1.000 & & \\
\hline
\end{tabular}




\begin{tabular}{|c|c|c|c|c|c|c|}
\hline \multicolumn{7}{|c|}{ Correlation } \\
\hline & Sig. (2-tailed) & 0.001 & 0.002 & & \multirow{3}{*}{1.000} & \\
\hline \multirow[t]{2}{*}{ E procurement } & $\begin{array}{l}\text { Pearson } \\
\text { Correlation }\end{array}$ & $.318^{*}$ & 0.081 & 0.071 & & \\
\hline & Sig. (2-tailed) & 0.012 & 0.532 & 0.583 & & \\
\hline Inventory & Pearson & & & & & \\
\hline \multirow[t]{2}{*}{ Training } & Correlation & $.472 * *$ & $.319^{*}$ & 0.183 & 0.206 & 1.000 \\
\hline & Sig. (2-tailed) & 0.000 & 0.012 & 0.153 & 0.107 & \\
\hline
\end{tabular}

The results revealed that inventory recording and financial performance are positively and significant related $(\mathrm{r}=0.463, \mathrm{p}=0.000)$. The results also revealed that stock auditing and financial performance are positively and significant related $(\mathrm{r}=0.427, \mathrm{p}=0.001)$. In addition, the results also revealed that $\mathrm{E}$ - procurement and financial performance are positively and significant related $(\mathrm{r}=0.318, \mathrm{p}=0.018)$. Lastly, the results also revealed that Inventory Management training and financial performance are positively and significant related $(r=0.472, p=0.000)$. These findings agreed with that of Chen, Hsu and Huang (2013) who found that both partners' and assistants' training have significantly positive effects on financial performance with the former occurring in the current and one-year-lagged periods and the latter occurring in the one-yearlagged and two-year-lagged periods

\subsection{Regression Analysis}

The results below presented the fitness of the regression model used in explaining the study phenomena.

\section{Table 8: Model Fitness}

\begin{tabular}{lc}
\hline Indicator & Coefficient \\
\hline $\mathrm{R}$ & 0.661 \\
$\mathrm{R}$ Square & 0.437 \\
Adjusted R Square & 0.398 \\
Std. Error of the Estimate & 0.441 \\
\hline
\end{tabular}

Inventory recording, stock auditing, E - procurement and Inventory management training were found to be satisfactory variables in financial performance .This was supported by coefficient of determination also known as the $\mathrm{R}$ square of $43.7 \%$. This meant that Inventory recording, stock auditing, E - procurement and Inventory management training explain $43.7 \%$ of the variations in the dependent variable which was financial performance. The results further meant that the model applied to link the relationship of the variables was satisfactory.

From the analysis, $43.7 \%$ variation in the dependent variable (financial performance) is explained by the model.

In statistics significance testing the p-value indicates the level of relation of the independent variable to the dependent variable. If the significance number found is less than the critical value 
also known as the probability value (p) which is statistically set at 0.05 , then the conclusion would be that the model is significant in explaining the relationship; else the model would be regarded as non-significant.

Table 9: Analysis of Variance

\begin{tabular}{|c|c|c|c|c|c|c|}
\hline & Sum of Squares & df & & Mean Square & $\mathbf{F}$ & Sig. \\
\hline Regression & 8.613 & & 4 & 22.153 & 11.062 & 0.000 \\
\hline Residual & 11.095 & & 57 & 0.195 & & \\
\hline Total & 19.708 & & 61 & & & \\
\hline
\end{tabular}

The results indicated that the overall model was statistically significant. Further, the results implied that the independent variables are good predictors of financial performance. This was supported by an F statistic of 22.153 and the reported p value $(0.000)$ which was less than the conventional probability of 0.05 significance level.

Table 10: Regression of Coefficients

\begin{tabular}{lcccc}
\hline & B & \multicolumn{1}{c}{ Std. Error } & t & Sig. \\
\hline (Constant) & -0.649 & 0.689 & -0.942 & 0.35 \\
Inventory recording & 0.293 & 0.132 & 2.213 & $\mathbf{0 . 0 3 1}$ \\
Stock Audit & 0.314 & 0.131 & 2.391 & $\mathbf{0 . 0 2 0}$ \\
E- procurement & 0.215 & 0.1 & 2.144 & $\mathbf{0 . 0 3 6}$ \\
Inventory Training & 0.355 & 0.126 & 2.811 & $\mathbf{0 . 0 0 7}$ \\
\hline
\end{tabular}

Regression of coefficients results revealed that inventory recording and financial performance are positively and significant related $(\mathrm{r}=0.293, \mathrm{p}=0.031)$. The table further indicates that stock audit and financial performance are positively and significant related $(r=0.314, p=0.020)$. It was further established that $\mathrm{E}$ - Procurement and financial performance were positively and significantly related $(\mathrm{r}=0.215, \mathrm{p}=0.036)$. Lastly the study established that inventory training and financial performance were also positively and significantly related $(r=0.355, p=0.007)$. These findings agreed with that of Chen, Hsu and Huang (2013) who found that both partners' and assistants' training have significantly positive effects on financial performance with the former occurring in the current and one-year-lagged periods and the latter occurring in the one-yearlagged and two-year-lagged periods.

Thus, the optimal model for the study is;

Financial Performance $=-0.649+0.293$ Inventory Recording +0.314 Stock Audit +0.263 E Procurement + 0.007 Inventory Management Training

\subsection{SUMMARY OF FINDINGS, CONCLUSION AND RECOMENDATION}

\subsection{Summary}

The findings revealed that there was a significant association between inventory recording and financial performance. The findings also revealed that there was a significant association between stock taking and financial performance. The findings also revealed that there was a 
significant association between E - procurement and financial performance. The findings revealed that there was a significant association between inventory management training and financial performance.

\subsection{Conclusion}

The study concluded that Inventory recording, stock auditing, E - procurement and inventory management training have a positive and a significant effect on financial sustainability. The study also concluded that effective implementation of strategic audit planning in county governments has not been successful due and this has resulted to little improved audit practices in the country and thus leading to poor performance in the county. The study also concluded that highly automated counties perform better than a county that still uses manual systems. The study also concluded that highly automated counties perform better than a county that still uses manual systems. The study also concluded that counties which conduct inventory training frequently perform better than counties which lag behind in inventory training. In addition, coaching and mentorship programs for employees leads to better employee performance

\subsection{Recommendations}

The study also recommends that the county governments adopting e-procurement ought to scale down on traditional procurement activities if the benefits of e-procurement are to be realized. Additionally, it is recommended that county governments should focus more on streamlining etendering, e-requisitioning and e-sourcing because a strong and significant relationship exists between those e-procurement processes and procurement performance in supermarkets.

\section{REFERENCES}

Amaka, C. P. (2012). The Impact of Internal Control System on The Financial Management of An Organization (A Case Study Of The Nigeria Bottling Company Plc, Enugu).Master's Thesis. Faculty of Management and Social Sciences Caritas University.

Carmeli, A., \&Tishler, A. (2004). The relationships between intangible organizational elements and organizational performance. Strategic management journal, 25(13), 1257-1278

Caruson, K., MacManus, S. A., \& McPhee, B. D. (2012).Cyber security Policy-Making at the Local Government Level: An Analysis of Threats, Preparedness, and Bureaucratic Roadblocks to Success.

Christopher, M. O., \& Kwasira, J. (2012). Determinants of Successful Implementation of Inventory Management Information System in Public Sector in Kenya: Survey of Nakuru County

Donald, K. Kombo., \&Delno L. A. Tromp. (2009). Proposal and Thesis Writing, An Introduction. Pauline Publications Africa. Nairobi, Kenya.

Dwivedi, N., \& Jain, A. K. (2005). Corporate governance and performance of Indian firms: The effect of board size and ownership. Employee Responsibilities and Rights Journal, 17(3), 161-172. 


\section{Www.iprjb.org}

Gaturu, I. N., \& Ngahu, S. (2013). Effect of computerized audit system on financial management at water resources management authority in Nairobi County, Kenya.

Hossain, A. (2015). Impact of inventory management on the financial performance of the firm: Al-Nawasi General Trading and Contracting Co.

Mary, M, Albert, O., \& Byaruhanga, J. (2015).Effects of Internal Control Systems on Financial Performance of Sugarcane out grower companies in Kenya.

Ochara, N. M. (2010). Assessing irreversibility of an E-Government project in Kenya: Implication for governance. Government Information Quarterly, 27(1), 89-97.

Sugut, O. C. (2014). The effect of computerized accounting systems on the quality of financial reports of nongovernmental organizations in Nairobi County, Kenya (Doctoral dissertation, University of Nairobi).

Usang, O. U. E., \& Salim, B. (2016). Local government financial condition and sustainable development of communities in Nigeria. Scholedge International Journal of Management \& Development ISSN 2394-3378, 3(1), 11-19.

Wambua, B. J., Okibo, W. B., Nyang'au, A. \& Ondieki, S. M. (2015). Effects of Inventory Warehousing Systems on the Financial Performance of Seventh Day Adventist Institutions: A Case of Adventist Book Centers (ABC), Kenya. International Journal of Business and Management, 10(4), 259 -264.

Ziaee, M. (2014). The effect of audit quality on the performance of listed companies in Tehran Stock Exchange. International Letters of Social and Humanistic Sciences, (21), 36-43. 